\title{
The Genetic Variations and Relationship of Madura Tobaccos (Nicotiana tabacum L.) Based on Molecular Characteristics
}

\author{
Fitri Nadifah"1,2, Budi Setiadi Daryono, ${ }^{2, *}$ \\ ${ }^{1}$ Diploma Program of Health Analyst STIKES Guna Bangsa, Yogyakarta, Indonesia \\ ${ }^{2}$ Faculty of Biology, Universitas Gadjah Mada, Jalan Teknika Selatan, Sekip Utara, \\ Yogyakarta 55281, Indonesia
}

\begin{abstract}
Madura has at least 22 genotypes of local tobaccos (Nicotiana tabacum L.). This diversity could potentially produce new genotype of tobaccos with superior characters. However, information of the genetic diversity of Madura tobaccos is still limited. The aim of this study was to determine the genetic variation and relationship of 24 genotypes of Madura tobaccos with Random Amplified Polymorphic DNA (RAPD) analysis. In this research we were used 6 single primers for amplification: (OPA-18, OPB12, OPB-14, OPC-1, OPC-8 and OPC-19) and 2 mixture primers ((OPB-12+OPC-8) and (OPC-1+OPC19)). Genetic similarity and clustering was analyzed with Unweighted Pair Group Method Arithmetic (UPGMA) method with Numerical Taxonomy and Multivariate Analysis System (NTSYS) version 2.10 software. From this research we found that OPA18425, OPB12450, OPC8500, (OPC19+OPC1)550 and OPC8800 can be used as specific markers. Polymorphic bands percentage with mixture primers was relatively equal with single primers $(<60 \%)$. The dendogram showed that Madura tobacco genotypes consist of 2 main clusters: cluster A (22 genotypes) and cluster B (2 genotypes: Bukabu Sa'ang and Prancak95). Madura tobaccos had high genetic similarity between genotypes ranging from 0.80-1.00.
\end{abstract}

Keywords: Nicotiana tabacum, RAPD, genetic variations

\section{Introduction}

Madura Island is one of the largest tobacco-producing area in Indonesia with $30-33 \%$ of the total tobacco plantation area in Indonesia (Ernawanto et al., 2007). Geographically, Madura environment is suitable for the growth of tobaccos because this plants is easily adapted to the local environment and also form genotype and phenotype characters. This adaptation led to the formation of various local tobacco genotype. Based on Amzeri et al. (2009), there are 22 genotype of tobaccos which is found in three tobacco-planting centers in Madura (Sumenep, Sampang and Pamekasan) and in Balai Penelitian Tanaman Pemanis dan Serat (Balittas) Malang.

A number of studies have been performed by hybridization to generate new

\footnotetext{
*Corresponding author:

Budi Setiadi Daryono

Faculty of Biology, Universitas Gadjah Mada, Jalan Teknika Selatan, Sekip Utara, Yogyakarta 55281, Indonesia

E-mail: bs_daryono@mail.ugm.ac.id
}

tobacco with superior character such as low nicotine level. A cross between Prancak-95 with local tobacco produce N1 and N2 genotype with nicotine levels 2-3.5\% (Balittas, 2007). Amzeri et al. (2009) has conducted exploration in four districts in Madura and found 22 genotype of local tobaccos. The study also provide information on Madura tobacco characters variability. However, information on the genetic variation and relationships between Madura tobaccos also required as a guide for plant breeding programs and conservation of germplasm.

Molecular marker technology has been widely used for genetic diversity identification because of its nature to detect high genetic variation, easy to implement, and reproducible. Random Amplified Polymorphic DNA (RAPD) is a molecular marker technique which has been widely applied to identify the genetic variation. This technique does not require the target DNA sequence and requires relatively small quantities of DNA samples. RAPD technique using a single primer (9-10 nucleotides) was 
used to generate a random DNA fragments (Liu and Zhang, 2008).

RAPD technique has been used for the identification of genetic variations in tobaccos (Sarala and Rao, 2008; Raju et al., 2009). In addition, RAPD is also widely used to detect the presence of markers associated with the existence of particular genes. Hu et al. (1995) use RAPD for the detection of markers associated with the expression of the gene that determines the content of linoleic acid in rapeseed.

Some researchers have modified the RAPD protocol, i.e. using the primer mixtures (Sall et al., 2000; Suardana et al., 2008). Two or more primers produced a number of new markers that are not found in single primer usage, but with a shorter average length of band (Hu et al., 1995). The aim of this research was to determine the genetic variation and relationships among 24 local Madura tobaccos based on molecular characters. This research used RAPD technique with single and mixture primers to determine its effectiveness in the detection of genetic variation among Madura tobaccos.

\section{Materials and Methods}

Tobacco plant samples provided by the Faculty of Agriculture, Trunojoyo University Madura, consisting 4 tobaccos from Balittas Malang (Cangkring-95, Prancak-95, Prancak N-1, Prancak N-2) and 20 Madura local tobaccos (Baruno, Hibrida, Jepon Kasturi, Jepon Kasturi Mawar, Talangkitan, Cangkring Dalar, Jepon Kenik, Jepon Moris-1, Jepon Moris-2, Prancak-96, Jepon Bojon, Berbeddih, Jepon Tarnyak, Cangkring Kuning, Danangan, Melati Tumpang, Bukabu Sa'ang, Bukabu, Virginia and Ismir).

DNA extraction of leaf samples is performed using Nucleon ${ }^{\mathrm{TM}}$ Phytopure isolation kit according to the manufacturer's instructions. Six single primers: OPA-18 (AGGTGACCGT), OPB-12 (TCGGCGATAG), OPB-14 (TCTGTGCTGG), OPC-8 (TGGACCGGTG), OPC-1 (TTCGAGCCAG), OPC-19 (GTTGCCAGCC) (Operon Technologies) and mixture primers: (OPB12+OPC-8) and (OPC1+OPC19) were used for RAPD-PCR amplification. Total volume of PCR reaction is $25 \mu 1$ consist of 2 $\mu \mathrm{l}$ of DNA template $(10 \rho g-1 \mu \mathrm{M}) ; 2.5 \mu \mathrm{l}$ of primer $(0.1-1 \mu \mathrm{M})$ and $20 \mu \mathrm{l}$ of Mega Mix Blue PCR master mix (Microzone). PCR reaction with double primers consists of $2 \mu$ l of template DNA; $2 \mu \mathrm{l}$ of primer and $19 \mu \mathrm{l}$ of PCR master mix. DNA amplification cycle was one cycle with a temperature of $94^{\circ} \mathrm{C}$ for 5 minutes, and 45 cycles of denaturation temperature of $94^{\circ} \mathrm{C}$ for $1 \mathrm{~min}$, annealing $36^{\circ} \mathrm{C}$ for 1 minute and elongation temperature $72^{\circ} \mathrm{C}$ for 2 minutes. The cycle ends with a post-elongation temperature $72^{\circ} \mathrm{C}$ for 7 minutes. The amplification results then resolved with agarose gel electrophoresis using 1.5\% agarose $(\mathrm{w} / \mathrm{v})$ and GoodView ${ }^{\mathrm{TM}}$ DNA stain (ECOLI).

Binary data produced from RAPD-PCR amplification is used to calculate the coefficients of genetic similarity of Dice from the Nei and Li (1979) formula. From the genetic similarity coefficient data, the analysis of grouping then was done by Numerical Taxonomy and Multivariate Analysis System for personal computer (NTSYSpc) version 2.10. Genetic similarity between genotypes based on genetic similarity coefficients or genetic distance was set using the Unweighted Pair Group Method Arithmetic (UPGMA). Genetic diversity among sample was set by POPGENE 1.32 program (Yeh et al., 1999). This analysis was to determine the value of genetic diversity based on the Nei's gene diversity (1973) and the percentage of polymorphic bands.

\section{Results and Discussion}

Amplification with PCR-RAPD technique produce random DNA fragments depicting genetic diversity of the Madura tobaccos. This can be seen from the number of polymorphic bands from electrophoresis profile. The results of DNA amplification using OPC-8 primer is presented in Figure 1. From the Figure 1, it can be seen that $500 \mathrm{bp}$ and $800 \mathrm{bp}$ bands are appear in all of the samples, except in sample 15 . With another primers, the 425, 450, 500, 550 and 800 bp bands also not appear in sample 15 . However, amplification with all of the primers were 

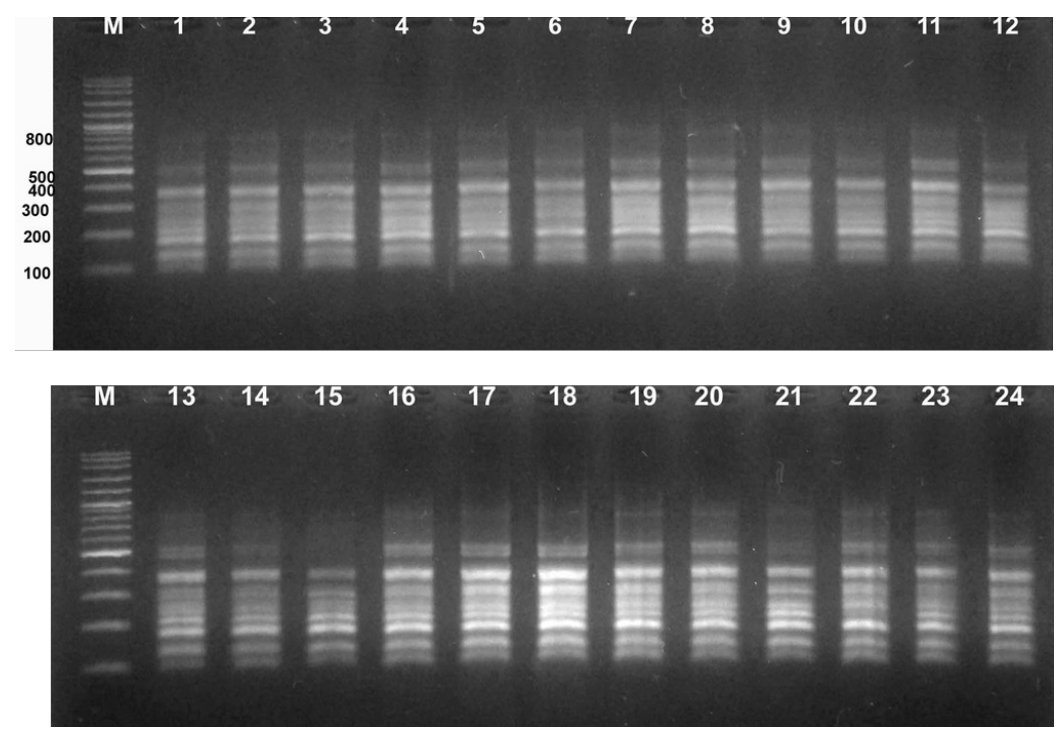

Figure 1. Electrophoresis visualization with OPC-8 primer. $M=$ DNA marker (Vivantis 100 bp); 1: Baruno; 2: Hibrida; 3: Jepon Kasturi; 4: Jepon Kasturi Mawar; 5: Talangkitan; 6: Cangkring Dalar; 7: Jepon Kenik; 8: Jepon Moris-1; 9: Jepon Moris-2; 10: Prancak-96; 11: Jepon Bojon; 12: Berbeddih; 13: Jepon Tarnyak; 14: Cangkring Kuning; 15: Prancak95; 16: Cangkring-95; 17: Prancak-N1; 18: Prancak-N2; 19: Danangan; 20: Melati Tumpang; 21: Bukabu Sa'ang; 22: Bukabu; 23: Virginia; 24: Ismir. DNA bands of $500 \mathrm{bp}$ and $800 \mathrm{bp}$ did not amplified in sample 15.

resulting specific markers OPA1 ${ }_{425^{\prime}} \mathrm{OPB} 12_{450^{\prime}}$ $\mathrm{OPC}_{500},(\mathrm{OPC} 19+\mathrm{OPC} 1)_{550}$ and $\mathrm{OPC} 8_{800}$. Another result is amplification with OPB-14 and OPC-8 primers generate more bands than Sarala and Rao (2008) and Raju et al. (2009) who were working with Indian local tobacco. This indicates that Madura local tobacco has greater genetic variation than Indian tobacco.

Amplifications result in total 53 DNA bands with 6 single primers and 14 bands with 2 mixtures primers (Table 1 and 2). This result is less compared to Daryono et al. (2015) that produce 54 DNA bands using 5 RAPD primers.

Amplification with mixture primers produce polymorphic band percentage that relatively equal with the single primers $(<60 \%)$. In addition, the usage of mixture primers in PCR-RAPD technique generates less amount of bands compared with single primers. In this case, there were imbalance distribution of primers in annealing side that will generate the dominance of one primer usage. Sall et al. (2000) mentioned it as a competition between primers in an amplification reaction. The lack of fragments occurs because there is only one dominant primer who serves. However, primer mixture produce two DNA bands that are not apparent from the single primer amplification. This is in accordance with the results of $\mathrm{Hu}$ et al., (1995).

Average length of bands generated by mixture primers is $264.29 \mathrm{bp}$, shorter than single primers (358.49 bp) (Table 1 and 2). This is in accordance with the results of Hopkins and Hilton (2001) which states that the size of PCR products with a single primer ranging from 0.2 to $2 \mathrm{~kb}$, and the size of the

Table 1. Monomorphic and polymorphic bands in Madura tobaccos with 6 single primers.

\begin{tabular}{|c|c|c|c|c|c|}
\hline Primer & Sequence & Total no. of bands & Monomorphic bands & Polymorphicbands & Polimorphic bands(\%) \\
\hline OPA-18 & 5'-AGGTGACCGT-3' & 5 & 2 & 3 & 60.00 \\
\hline OPB-12 & $5^{\prime}$-CCTTGACGCA-3' & 7 & 5 & 2 & 28.57 \\
\hline OPB-14 & 5'-TCCGCTCTGG-3' & 14 & 0 & 14 & 100.00 \\
\hline OPC-1 & $5^{\prime}$-TTCGAGCCAG-3' & 8 & 3 & 5 & 62.50 \\
\hline OPC-8 & 5'-TGGACCGGTG-3' & 9 & 7 & 2 & 22.22 \\
\hline OPC-19 & $5^{\prime}$-GTTGCCAGCC-3' & 10 & 4 & 6 & 60.00 \\
\hline Total & & 53 & 21 & 32 & \\
\hline \multicolumn{2}{|c|}{ Average of polymorphic bands( $\%)$} & \multicolumn{3}{|c|}{55.55} & \\
\hline \multicolumn{2}{|c|}{ Average of bands length(bp) } & \multicolumn{3}{|c|}{358.49} & \\
\hline
\end{tabular}


Table 2. Monomorphic and polymorphic bands in Madura tobaccos with mixture primers.

\begin{tabular}{lcccc}
\hline Primers & Total no. of bands & Monomorphic bands & Polymorphicbands & Polimorphic bands(\%) \\
\hline (OPB-12 + OPC-8) & 7 & 3 & 4 & 57.14 \\
(OPC-1 + OPC-19) & 7 & 3 & 4 & 57.14 \\
\hline Total & 14 & 6 & 8 & 57.14 \\
\hline Average of polymorphic bands(\%) & \multicolumn{5}{c}{264.29} \\
Average of bands length(bp) & & \multicolumn{5}{c}{} \\
\hline
\end{tabular}

fragments of mixture primer decreased from 0.1 to $3 \mathrm{~kb}$. Decreasing of fragment length can occur because of the annealing side of one primer is on amplification areas belonging to the other primer (Hopkins and Hilton, 2001). As a result, DNA fragments are shorter to be amplified.

Binary data from electrophoresis profiles then analyzed with POPGENE 1.32 program (Yeh et al., 1999). From the result, the percentage of polymorphic bands and gene diversity per band was $59.70 \%$ and $0.2003 \pm 0.1886$, respectively. This percentage of polymorphic bands result is consistent with the analysis of DNA bands from amplification which is less than $60 \%$.

The similarity value between Madura tobaccos ranging from $80-100 \%$. This indicates that Madura tobacco has high genetic similarity, in line with relatively low of diversity result. Similarity value obtained in this study is quite different with Amzeri et al. (2009) which suggests that the similarity between Madura tobaccos based on morphological characters is ranging between 45-96\%. According to Strelchencko et al. (1996), the use of morphological characters for genetic diversity analysis cannot describe the genetic control. Molecular techniques analysis can be used to describe the whole genome without relying on phenotypic characters.

Figure 2 showed the dendogram of 24 genotypes of Madura tobaccos. They were clustered into two main clusters: cluster A and $\mathrm{B}$ with genetic distance 0.82 . Cluster A consist of 22 genotypes and clumped into clusters $C$ and D. Some genotypes in cluster A have high similarity $(>0.95)$. This indicates the high similarity between tobacco genotypes. Prancak-95 and Bukabu Sa'ang segregated and formed their own groups in cluster B. To obtain the desired variety through crossing is required the establishment of segregated population. Parental candidates must have a large degree of diversity. In this dendogram we can see that Prancak-95 and Bukabu Sa'ang segregated with other clusters and have the lowest similarity with other genotypes.

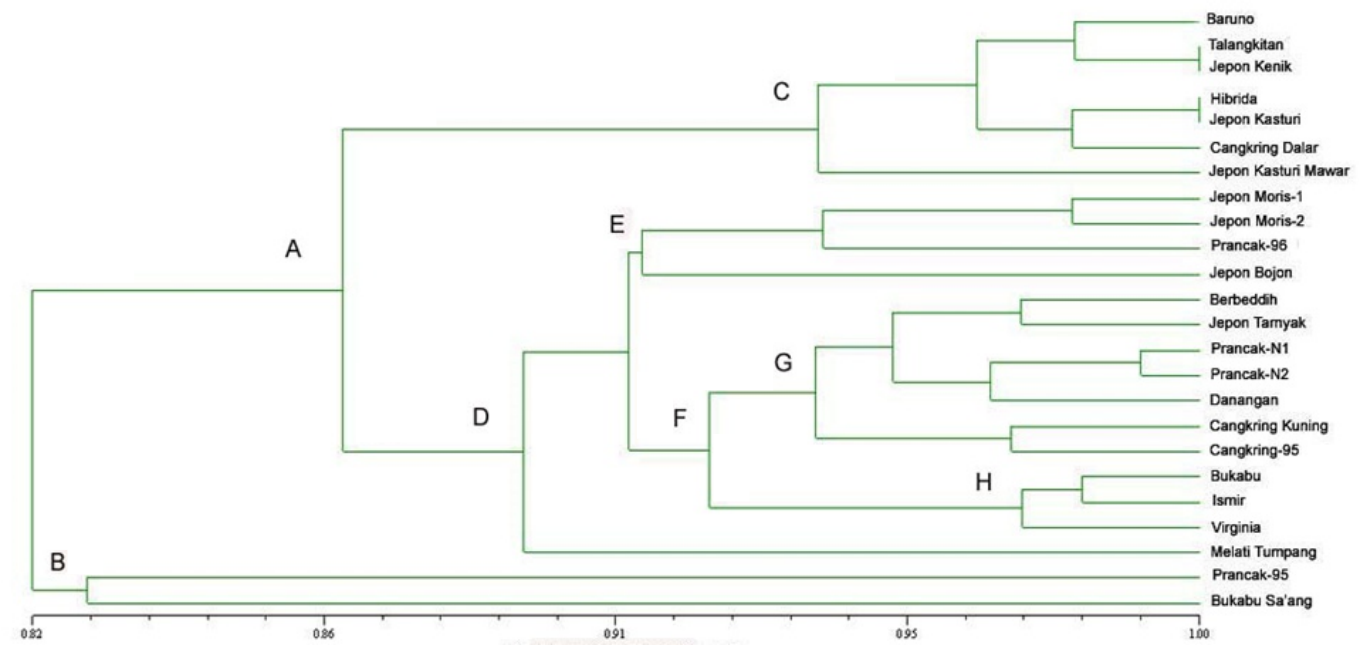

Figure 2. Dendogram of 24 genotypes of Madura tobaccos. All tobaccos clustered into 2 main clusters: cluster A and B. Prancak-N1 and Prancak-N2 shared highest similarity than others in cluster A. Prancak-95 as cruciferous parent of Prancak-N1 and N2 segregated and formed their own groups in cluster B. 
Therefore both genotypes can be used as parental for producing desired varieties (Daryono et al., 2015)

The results of this study has indicate that RAPD is a reliable technique that can be used for identification of genetic variation and relationship of local Madura tobaccos. Genetic diversity of Madura tobacco constitute a wealth of genetic resources that should be conserved. Information about genetic variation and relationships of Madura tobaccos is very important for the plant breeding programs. Hybridization can be done between the two genotype by looking at relationship and superior traits. However, the selection of plants with superior traits should maintain the existence of local genotype to avoid the disappearance of local genotype in nature.

\section{Conclusions}

Amplification using 6 RAPD primers and two couple of double primers generate

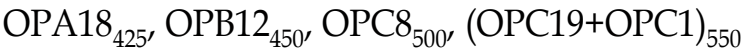
and $\mathrm{OPC}_{800}$ as specific markers. Amplification with mixture primers produces polymorphic bands percentage which is relatively equal with single primers $(<60 \%)$, but with a shorter average length of DNA bands. Based on the dendogram, 24 genotypes of Madura tobaccos clustered into cluster A and cluster B. Cluster A consist of 22 genotypes while cluster $B$ consist of 2 genotypes: Prancak-95 and Bukabu Sa'ang. Both genotypes can be used as parental for producing desired varieties because cluster B segregated and have the lowest similarity with other genotypes. Madura tobaccos have high genetic similarity between genotypes ranging from 0.80-1.00.

\section{Acknowledgments}

We would like to thank Mr. Achmad Amzeri, S.P., M.P. who gave the DNA samples which really supported the course of this research.

\section{References}

Amzeri, A., Badami, K., Daryono, B.S., Rachmawati, D. (2009) Pemanfaatan sumber daya genetik tembakau (Nicotiana tabacum L.) lokal Madura untuk pemuliaan dan pelestarian plasma nutfah. Laporan Hibah PEKERTI. LPPM Universitas Trunojoyo.

Balai Penelitian Tanaman Tembakau dan Serat. 2007. Akselerasi alih teknologi tembakau Madura rendah nikotin. Warta Penelitian dan Pengembangan Pertanian 29(3): 10-11.

Daryono, B.S., Amzeri, A., Badami. K. 2015. Kekerabatan tembakau madura (Nicotiana tabacum L.) berdasarkan karakter molekular. Agrovigor., 8(1), 73-78.

Ernawanto, D., Kartono, G., Suwarso, Moerdjiati. (2007) Tembakau Madura. Indonesia: Balai Pengkajian Teknologi Pertanian Jatim.

Hopkins, K.L., Hilton, A.C. 2001. Use of multiple primers in RAPD analysis of clonal organisms provides limited improvement in discrimination. BioTechniques, 30, 1262-1267.

Hu, J., van Eysden, J., Quiros, C.F. 1995. Generation of DNA based markers in spesific genome regions by two-primer RAPD reactions. Genome Res., 4, 346-351.

Liu, X.Z., Zhang, H. Y. 2008. Advance of molecular marker application in the tobacco research. Afr. J. Biotechnol., 7(25), 4827-4831.

Nei, M., Li, W H., 1979. Mathematical model for studying genetic variation in terms of restriction endonucleases. Proc. Natl. Acad. Sci. 76(10): 5269-5273.

Raju, K.S., Sheshumadhav, M., Chandrasekhararao, C., Murthy, T.G.K. 2009. Molecular diversity in genus Nicotiana as revealed by randomly amplified polymorphic DNA. Indian J. Biotechnol., 8(1), 61-66.

Sall, T., Lind-Hallden, C., Hallden, C. 2000. Primer mixtures in RAPD analysis. Hereditas, 132(2000), 203-208.

Sarala, K, Rao, R.V.S. 2008. Genetic diversity in Indian FCV and Burley tobacco cultivars. J. Genet., 87(2), 159-163.

Strelchenko, P.P., Gubareva, N.K, Kovalyova, O.N., Graner, A. (1996) Geographical and breeding trends within Eurasian cultivated barley germplasm revealed 
by molecular markers. In: Plant Genetic Resources: Characterization and Evaluation New Approaches to Improved Use of Plant Genetic Resources. Japan: National Institute of Agrobiological Resources Tsukuba.

Suardana, I.W, Artama, W.T., Asmara, W., Daryono, B.S. 2011. Studi epidemiologi agen zoonosis Escherichia coli O157:H7 melalui analisis random amplification of polymorphic DNA (RAPD). Jurnal Veteriner, 12(2), 142-151.

Wiriadinata, H,J., Mogea, P., Nasution, R.E., Rugayah, Sunarti, S. 1993. Jenis-jenis Tumbuhan Langka Indonesia. Proceeding Seminar Hasil Litbang SDH. Puslitbang Biologi LIPI: 58-67.

Yeh, F.C., Yang, R.C., Boyle, T.B.J., Ye, Z.H., Mao, J.C. (1999) POPGENE 1.32, The User-Friendly Shareware for Population Genetic Analysis. Molecular Biology and Biotechnology Center. University of Alberta Edmonton. 